\title{
ウエハのウエットエッチング法と洗浄と清浄度
}

\author{
松井淳 ${ }^{\mathrm{a}}$
}

${ }^{a}$ (株) MTK（） 246-0008 神奈川県横浜市瀬谷区五貫目町 8-5）

\section{Wet Etching Method, Cleaning and Cleanness for Semiconductor Wafer}

\section{Jun MATSUI ${ }^{\text {a }}$}

${ }^{\mathrm{a}}$ MTK Co,. Ltd.(8-5, Gokanme-cho, Seya-ku, Yokohama-shi, Kanagawa 246-0008)

Keywords : Etching, Cleaning, Cleanness, Particle, Semiconductor, Contamination

\section{1.はじめに}

半導体デバイスの製造は, 広く半導体デバイスが市場に販 売され始めた半世紀前から現在に至るまでパーティクルなど の不純物との戦いであった。半世紀初頭には既に，どのよう な不純物が半導体デバイスにどのような悪影響を与えるかに ついては理解されていた（表 1)。半導体デバイス製造におけ る不純物としては，大きく分類すると，パーティクル，残椬， 金属，有機物に分けられる。パーティクルは配線パターンを 正常に形成するのを妨げて, 信号オープン不良やショート不 良を引き起こす。また，ドライエッチングにより生成される ポリマー生成物のような残椬は，もし，完全に除去されない 場合には，同じく信号オープン不良やショート不良，さらに， 配線コンタクト抵抗大による動作スピード低下を引き起こす 場合がある。金属不純物については，重金属，アルカリ金属 などにより半導体デバイスに与える影響の差はあるものの,

一概には，ゲート酸化膜の耐圧劣化 (TDDB), PN 接合にお ける微小電流リーク, トランジス夕動作不安定化 $\left(\mathrm{V}_{\mathrm{th}}\right.$ シフト) を引き起こす。また，有機物については，薬液やレジストの 残椬が考えられるが, ゲート酸化膜の耐圧劣化 (TDDB), 配
線コンタクト抵抗大による動作スピード低下, 配線パターン 破壞によるオープン・ショート不良, 配線コンタクト抵抗大 による動作スピード低下を引き起こす。

半導体デバイス製造に関わる関係者の多大な努力により, 金属不純物と有機物不純物については薬液洗浄により解決で きた部分が多く, 現在では公には大きな問題としてはクロー ズアップされていない。ただし，パーティクル(含む残渣)に ついては, 現在においても半導体デバイスの歩留まりを低下 させる最大の要因となっている。

以降は, 半導体デバイスの洗浄, 清浄度について不慣れな 方においても理解しやすいように解説した。

\section{2. パーティクルとの闘い}

前項にも述べたが，半導体デバイスの製造は，半世紀前か ら現在に至るまでパーティクルとの戦いであった。一概に パーティクルと言っても, その発生源は多岐にわたる。大気 中の塵については, クリーンルーム建設，ウエハ搬送自動化， SMIF, FOUPなどの局所運搬ボックスにより大幅に解決さ れた。現在では, パーティクルの主な発生源は, 半導体デバ イスを製造する装置であると考えられている。そのため, 半

表 1 ウエハ表面の不純物が LSI デバイス品質に及ぼす影響 ${ }^{2)}$

\begin{tabular}{|c|c|c|}
\hline \multicolumn{2}{|r|}{ 不純物種類 } & LSI デバイス品質への影響 \\
\hline パーティクル & $\begin{array}{l}\text { 大気浮遊塵 } \\
\text { 人体 } \\
\text { 装置からの発塵 } \\
\text { ガス, 薬品, CMP スラリー中の塵 } \\
\end{array}$ & ・配線パターン破壊によるオープン・ショート不良 \\
\hline 残椬 & ドライエッチング生成物 & $\begin{array}{l}\text { ·配線パターン破壊によるオープン・ショート不良 } \\
\text { ・配線コンタクト抵抗大による動作スピード低下 }\end{array}$ \\
\hline \multirow{3}{*}{ 金属 } & $\mathrm{Fe}, \mathrm{Ni}, \mathrm{Cr}$ などの重金属 & $\begin{array}{l}\text { ・ゲート酸化膜の耐圧劣化(TDDB) } \\
\text { •PN 接合における微小電流リーク } \\
\text { ・ライフタイム低下 }\end{array}$ \\
\hline & $\mathrm{Na}, \mathrm{K}$ などのアルカリ金属 & ・トランジスタ動作不安定化 ( $\mathrm{V}_{\mathrm{th}}$ シフト) \\
\hline & $\mathrm{Cu}, \mathrm{Au}$ & $\begin{array}{l}\text { ・ライフタイム低下 } \\
\text { ・ゲート酸化膜の耐圧劣化(TDDB) }\end{array}$ \\
\hline \multirow{2}{*}{ 有機物 } & 液残椬 (リンス, 乾燥不足) & $\begin{array}{l}\text { ・ゲート酸化膜の耐圧劣化(TDDB) } \\
\text { ・配線コンタクト抵抗大による動作スピード低下 }\end{array}$ \\
\hline & レジスト残椬 & $\begin{array}{l}\text { ·配線パターン破壊によるオープン・ショート不良 } \\
\text { ・配線コンタクト抵抗大による動作スピード低下 }\end{array}$ \\
\hline
\end{tabular}


表 2 ITRS における半導体前工程でのロードマップ表

\begin{tabular}{|c|c|c|c|c|c|c|c|}
\hline 生産年 & 2016 年 & 2017 年 & 2018 年 & 2019 年 & 2020 年 & 2021 年 & 2022 年 \\
\hline $\begin{array}{c}\text { DRAM ハーフピッチ }(\mathrm{nm}) \\
\text { コンタクト穴部 }\end{array}$ & 20 & 17.9 & 15.9 & 14.2 & 12.6 & 11.3 & 10 \\
\hline MPU ASIC ゲート幅寸法 $(\mathrm{nm})$ & 15.3 & 14 & 12.8 & 11.7 & 10.9 & 9.7 & 8.9 \\
\hline 管理必要なパーティクル最小寸法 $(\mathrm{nm})$ & 10 & 8.9 & 8 & 7.1 & 6.3 & 5.6 & 5 \\
\hline
\end{tabular}

導体デバイスを製造する会社は，毎日，製造装置のクリーニ ングを実施し，ゴミ検と言われるパーティクル検査を日常 行っている。また，製造装置会社は装置構造を工夫して極力， パーティクルが発生しない装置の開発に苦心している。

半導体デバイスの配線パターンの高集積化にともない, 半 導体デバイスに形成される配線のサイズが年々, 縮小してき ている(所謂, ムーアの法則である)。表 2 に国際的な半導体 デバイスの標準化機構である ITRS による最先端半導体デバ イスのロードマップを示した。本年 2016 年においては, DRAM コンタクト穴間隔のハーフピッチが $20 \mathrm{~nm}(0.02 \mu \mathrm{m})$, MPU ASIC ゲート幅寸法が $15.3 \mathrm{~nm}(0.0153 \mu \mathrm{m})$ と記述して おり, 2020 年には DRAM コンタクト穴間隔のハーフピッチ が $12.6 \mathrm{~nm}(0.0126 \mu \mathrm{m})$, MPU ASIC ゲート幅寸法が $10.9 \mathrm{~nm}$ $(0.0109 \mu \mathrm{m})$ と記述されている。以上の配線パターンを正常 に形成するために，ITRS では管理必要なパーティクル最小 寸法を規定している。それによれば，2016 年には，管理必 要なパーティクル最小寸法として $10 \mathrm{~nm}$ と規定し, 2020 年 では $6.3 \mathrm{~nm}$ と規定している。筆者の経験によれば, これは 厳しすぎる規定サイズに思える。

理由は, 実際のパーティクルは 3 次元であり不定形な場合 がほとんどであり, また, 配線形成時の成膜工程やドライエッ チング工程ではパーティクルの斜め方向からも反応するケー スがあるため, パーティクルの直径よりも小さな配線パター ンを歩留まり的には正常に形成できるケースもあると感じて いる。例えば, MPU ASIC ゲート幅最小寸法が $15.3 \mathrm{~nm}$ の半 導体デバイスを正常に製造するためには，同程度サイズ $15 \mathrm{~nm}$ レベルのパーティクルを管理する必要があると考える。

\section{3 . シリコンウエハの主なウエットエッチングエ程・用途}

半導体製造工程で行われるウエットエッチング工程と，使 用薬液について紹介する(表 3)。ウエハ表面では, LSI 配線

表 3 主なウエットエッチング工程・用途

\begin{tabular}{|c|c|c|}
\hline $\begin{array}{l}\text { ウエットエッ } \\
\text { チング箇所 }\end{array}$ & 工程·用途 & 使用薬液 \\
\hline \multirow[b]{2}{*}{ ウエハ表面 } & $\begin{array}{l}\cdot \mathrm{LSI} \text { 配線形成 } \\
\quad \cdot \mathrm{Al}, \mathrm{Al}-\mathrm{Cu}, \mathrm{Al}-\mathrm{Si}-\mathrm{Cu} \\
\quad \cdot \mathrm{SiO}_{2} \text { 膜 } \\
\end{array}$ & $\begin{array}{l}\mathrm{H}_{3} \mathrm{PO}_{4} \\
\mathrm{BHF}\left(\mathrm{HF} / \mathrm{NH}_{4} \mathrm{~F}\right)\end{array}$ \\
\hline & $\begin{array}{c}\text { LSI 配線形成後の不要膜除去 } \\
\cdot \text { ・フォトレジスト除去 } \\
\cdot \mathrm{Si}_{3} \mathrm{~N}_{4} \text { 膜除去 } \\
\cdot \mathrm{SiO}_{2} \text { 膜除去 } \\
\end{array}$ & $\begin{array}{l}\text { 硫酸 / 過酸化水素水, 有機溶剂 } \\
\text { 高温 } \mathrm{H}_{3} \mathrm{PO}_{4} \\
\text { フッ化水素酸, } \mathrm{BHF}, \mathrm{HF} / \mathrm{H}_{2} \mathrm{O}_{2}\end{array}$ \\
\hline ウエハ端面 & $\begin{array}{c}\text { ·端面パーティクル発生防止 } \\
\text { のための端面膜エッチング }\end{array}$ & フッ化水素酸, $\mathrm{HF} / \mathrm{HNO}_{3}$ \\
\hline ウエハ裏面 & 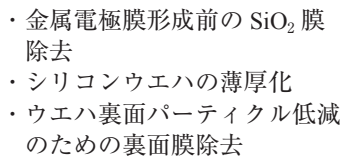 & $\begin{array}{l}\text { フッ化水素酸 } \\
\mathrm{HF} \mathrm{HNO}_{3} \\
\text { フッ化水素酸 }\end{array}$ \\
\hline
\end{tabular}

を形成するために今では殆どの半導体デバイスでは, ドライ エッチング方式を使用している。ドライエッチングはウエッ トエッチングに比較して異方性に優れ，微細な配線を形成す るためには有利なためである。ウエットエッチングは膜を等 方的にエッチングするため, 微細な配線を形成するのには不 利であり，使用できる配線が限られる。最上層の $\mathrm{Al}$ 系配線 で使用されるケースがある。ドライエッチングよりも，安価 な装置で形成できるためである。また, コンタクト穴やスルー ホール穴を形成する際に，その後の成膜時のカバレッジを良 くするために, 先ず BHF 薬液でウエットエッチングするケー スがある。一方, 現在の半導体デバイス製造工程で一番使用 する目的として多いのは, やはり, 配線形成後に不要になっ た膜を除去することであろう。例として，ドライエッチング 終了後のレジスト膜除去(レジスト剥離とも云う) や, LOCOS 配線形成後の $\mathrm{Si}_{3} \mathrm{~N}_{4}$ 膜除去や, イオン注入工程後の $\mathrm{SiO}_{2}$ 膜除去などである。

ウエハ端面部におけるウエットエッチングについては, 比 較的新たに注目され採用された技術である。一番のキッカケ は，半導体デバイスの歩留まりが低下して，その原因を調査 したところ, ウエ八端面部から膜が剥離して, その膜がウエ 八表面に移動付着したことだったと記憶している。半導体デ バイスの高集積化に伴い, 多くの膜種が積層されるが, 特に ウエハ端面部は膜応力が解放されやすい場所であり，しかも， 各膜種どうしが必ずしも密着性が強くない場合には, 容易に 膜が剥離されてしまう(図 1)。特にCMP工程後に膜剥がれ が発生しやすい。したがって，対策としては端面部の膜が剥 がれる前に，膜を除去してしまうことである。例えば，酸化 膜系膜の場合にはフッ化水素酸液で，また， $\mathrm{Ti}$ 等金属膜系 膜の場合にはフッ化水素酸と硝酸との混合薬液などでエッチ ング除去する。

ウエハ董面部におけるウエットエッチングについては，3

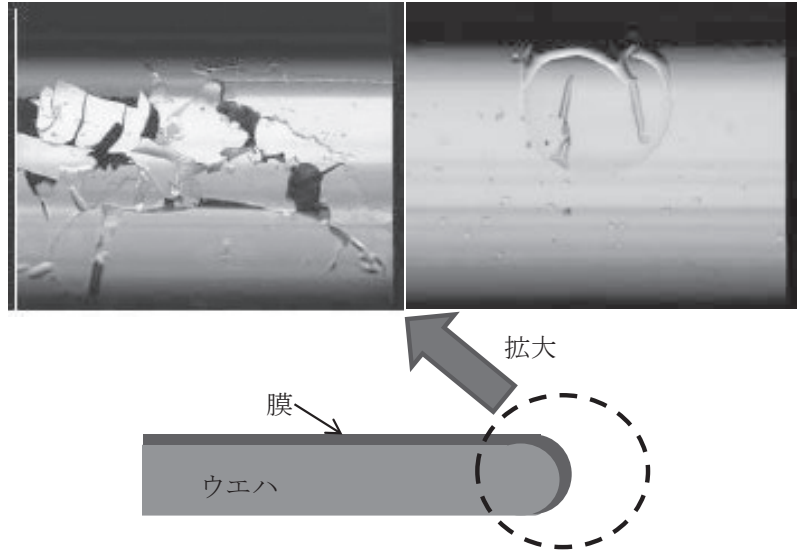

図 1 ウエハ端面部の膜剥がれ 


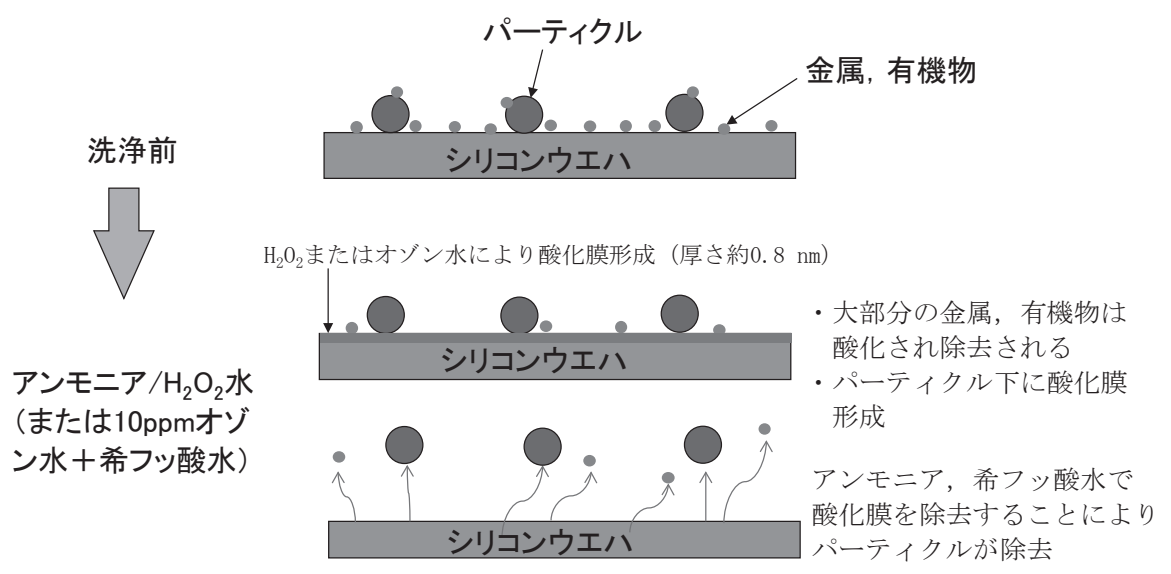

図 2 パーティクル・金属・有機物除去メカニズム

種類に分類される。先ずは，ウエハ裏面に電極用金属膜が搭 載される場合に，金属とウエハとの間に良好なオーミックを 得るために，金属成膜前に自然酸化膜などの酸化膜を除去す る目的である。通常はフッ化水素酸液を使用する。次に，ウ エハの厚さを薄くする目的である。ウエハ表面に配線を形成 終了した後に，最終的にウエハ厚さを通常 $150 \mu \mathrm{m}$ 以下に薄 くするのであるが, 通常は研削により薄くしたのちに, 研削 でウエハ内部に発生した潜傷を除去し, ウエハ強度を回復さ せるために，フッ化水素酸と硝酸の混合薬液を使用してウエ 八董面をわずかにエッチングする。最後は，ウエハ董面に付 着したパーティクルを除去する目的であるが, ウエハ董面に 付着したパーティクルは，特にフォトリソ工程において， フォーカス不良を引き起こしてしまうことがある。また，ウ エハ裏面のパーティクルは CVD やドライエッチング装置な どに使用されている静電容量チャックでのウエハ搬送不良を 発生させることがある。パーティクル除去のためには, ウエ 八董面に形成された不要な膜を除去することにより同時に パーティクルも除去できるケースが多い。通常は，フッ化水 素酸液を使用する。このように，ウエハ董面といえども，も はや，パーティクル管理は絶対に必要な時代となっている。

\section{4. シリコンウエハの洗浄方法について}

半導体製造工程の重要な一つである洗浄と使用薬液につい て紹介する(表 4)。

前にも述べたが，洗浄する対象物としては 3 つに分類され る。以降，それぞれの洗浄方法について述べることとする。

先ずは，パーティクル除去(洗浄)であるが，通常使用され る薬液はアンモニアと過酸化水素水の混合液である。略して APM (Ammonium Hydrogen-Peroxide Mixture) と呼ばれる。混 合比率, 液温度, 洗浄時間などは各社ノウハウとなっている が，一般的にはアンモニア：過酸化水素：純水 $=1: 1$ $10: 20 \sim 100$, 温度 $40 \sim 70{ }^{\circ} \mathrm{C}$ 。洗浄時間 30 秒 $~ 4$ 分が使 用されている。

昨今注目されているのは，オゾン水や水素水などの機能水 による洗浄である。APM などの薬液使用コストは大きなため, 費用削減を目的として，機能水をすでに採用開始した会社も 多々あるようである。また, 薬液費用, 排水・排気などの付 帯設備の軽減が図れるエコな観点からも今後, さらに注目さ
れると推定する。

図 2 にパーティクル，金属不純物，有機不純物が洗浄され るメカニズムの例を示した。

APM 液中の過酸化水素水の働きによりシリコンウエハ表 面には $0.8 \mathrm{~nm}$ 程度の極めて薄い酸化膜が形成される。オゾ ン水(オゾン濃度 $10 \mathrm{ppm}$ 程度, 温度 $25^{\circ} \mathrm{C}$ 以下) 使用の場合に はオゾンの働きにより, 同じく $0.8 \mathrm{~nm}$ 程度の極めて薄い酸 化膜が形成される。さらに, APM 液中のアンモニアは形成 された酸化膜をエッチング除去する働きがある。酸化膜が除 去されると同時に，パーティクル，金属不純物，有機不純物 もリフトオフ作用により除去されることになる。APM 液はア ルカリ性であるため, パーティクルなど不純物とウエハを同 じマイナスに帯電し，お互いが離れようとする作用を利用す るゼー夕電位理論も薬液選定には重要であるが, 詳細につい ては今回は割愛する。オゾン水を利用する場合には, オゾン 水処理の次の処理として $1 \%$ 以下の薄いフッ酸水を使用する。

次は, 金属除去(洗浄)であるが, 金属成分を酸化・溶解义 カニズムを利用して除去することが必要である。一般的には， 塩酸と過酸化水素水との混合液 (略称 HPM) や, 硫酸と過酸 化水素水の混合液(略称 SPM) が使用される場合が多い。酸 化・溶解効率を高めるために $60{ }^{\circ} \mathrm{C}$ 以上の高温で使用される。 また, フッ素に次ぐ高い酸化ポテンシャルを持つオゾン水(オ ゾン濃度約 $10 \mathrm{ppm}, 25^{\circ} \mathrm{C}$ 以下) も高性能とコスト低減の観点 から採用が広がっているようである。

次に有機物除去 (洗浄)について述べる。レジストを除いて ウエハ表面に付着する有機物として大きな固体状のものは殆 ど無いと考えられる。したがって，パーティクルや金属不純

表 4 シリコンウエハ洗浄に使用される主な薬液

\begin{tabular}{|c|l|c|}
\hline 目的 & \multicolumn{1}{|c|}{ 薬液 } & 略称 \\
\hline \multirow{3}{*}{ パーティクル除去 } & アンモニア/過酸化水素水 & $\mathrm{APM}$ \\
\cline { 2 - 3 } & オゾン水+希フッ酸水 & $\mathrm{O}_{3}$ 水 \\
\cline { 2 - 3 } & 水素水 & 水素水 \\
\hline \multirow{3}{*}{ 金属不純物除去 } & 塩酸/過酸化水素水 & $\mathrm{HPM}$ \\
\cline { 2 - 3 } & 硫酸/過酸化水素水 & $\mathrm{SPM}$ \\
\cline { 2 - 3 } & オゾン水 & $\mathrm{O}_{3}$ 水 \\
\hline \multirow{2}{*}{ 有機物除去 } & 硫酸/過酸化水素水 & $\mathrm{SPM}$ \\
\cline { 2 - 3 } & オゾン水 & $\mathrm{O}_{3}$ 水 \\
\hline
\end{tabular}




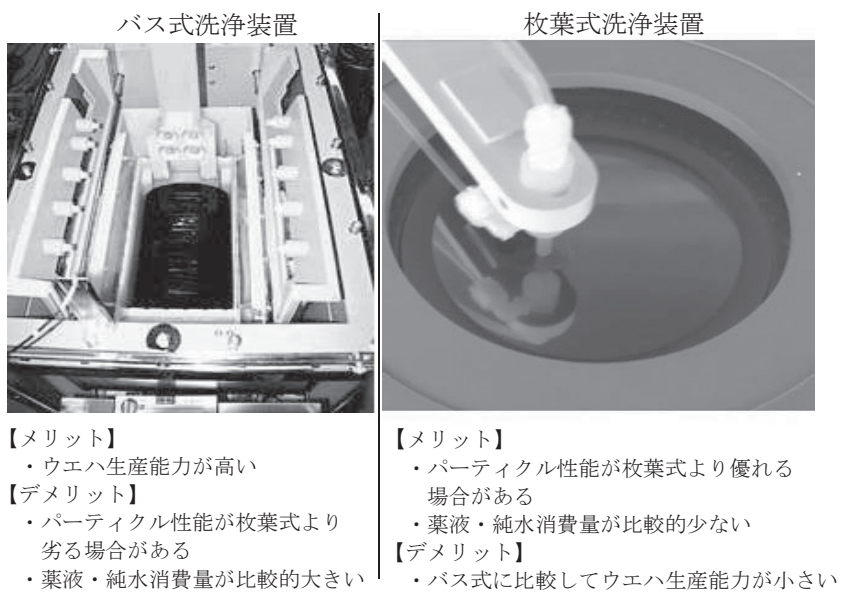

図 3 洗浄装置のタイプ

物を洗浄するための APM や HPM（または SPM）により，有 機物も除去洗浄されている。

最後に，一般的に多くの半導体デバイスを製造している会 社・研究機関で採用されている洗浄レシピについてであるが, $\mathrm{APM} \rightarrow$ 純水リンス $\rightarrow \mathrm{HPM}($ または $\mathrm{SPM}) \rightarrow$ 純水リンス 燥の順序で洗浄構成している。このレシピにより, パーティ クル，金属・有機不純物が殆ど全て洗浄できている。

\section{5. 洗浄装置タイプについて}

洗浄装置について紹介する。洗浄装置にはバス式洗浄装置 と枚葉式洗浄装置の 2 つに分類される(図 3 )。それぞれの装 置におけるメリットとデメリットを記述する。

バス式洗浄装置のメリットは, 何といっても枚葉式洗浄装 置に比較してウエハ生産性が高いことである。25枚または 50 枚のウエハを一度にバス槽内へ投入して洗浄する。一方, デメリットはパーティクル性能が枚葉式と比較して劣る場合 が多いことである。つまり，バス式ではウエ八表面に付着し ているパーティクルは，洗浄槽内で一旦はウエハから離れる。 そのパーティクルは, 槽内の薬液や純水中に存在している。 その後, ウエ八を次の洗浄槽へ移動させるときにウエ八は槽 内液の上部へ引き上げられるが，その際に，槽内のパーティ クルが再度, ウエ八表面に付着する場合が多い(厳密には薬 液種類にも依存し，問題にならない場合もある)。

槽内のパーティクルを除去するためにフィルターを通過さ せて液循環させているが, 完全にパーティクルをフィルター にて除去することは現時点ではできていないようである。ま た, 薬液・純水消費量が, 枚葉式装置に比較して大きいこと がデメリットである。

一方, 枚葉式洗浄装置のメリットは, パーティクル性能が バス式に比較して良好であることである。液中に存在する パーティクルをフィルターにより予馀去された薬液・純水 をウエハに当てるため, 液からはウエハ表面にはフィルター 径以上のパーティクルは付着しない。

また，薬液・純水消費量が，バス式装置に比較して小さい ことがメリットである。通常，ウエハ 1 枚当たり，純水使用 は約毎分 1 リッターである。デメリットは, バス式洗浄装置 に比較してウエ八生産性が小さいことである。そのため, 生
表 5 管理必要なウエハ表面清浄度指標と検査手法

\begin{tabular}{|c|l|c|}
\hline 検查測定物 & \multicolumn{1}{|c|}{ 検查手法 } & 検出限界 \\
\hline パーティクル & $\cdot$ レーザ式パーティクル検查装置 & 約 $30 \mathrm{~nm}$ \\
\hline \multirow{2}{*}{ 金属不純物 } & $\cdot$ ICP-MS (または TXRF) & $1 \mathrm{E} 9$ atoms $/ \mathrm{cm}^{2}$ 以下 \\
\cline { 2 - 3 } & ·再結合ライフタイム & 単位 $: \mu \mathrm{sec}$ \\
\hline 有機物 & $\cdot \mathrm{GC} / \mathrm{MS}$ & $20 \mu \mathrm{g} /$ ウエハ以下 \\
\hline
\end{tabular}

産性を補うために, 1 洗浄装置あたり処理チャンバーを 10 チャンバー程度設ける場合もある。

このようにして, バス式洗浄装置と枚葉式洗浄装置におい て特徵があるため, 半導体デバイスを製造する各社は, 製造 する半導体デバイスがどの配線サイズ世代(ノード世代)の製 品であるか，また，洗浄目的・工程により採用する装置夕イ プを使い分けている。1例を言えば，12 インチサイズウエハ は最先端な半導体デバイスを製造する場合が殆どであるが, つまり，パーティクルは極めて小さなものまで管理する必要 があるため，枚葉式洗浄装置を採用する傾向が強い。

\section{6. ウエハ表面の清浄度について}

ウエハ表面の清浄度について紹介する。ウエハを洗浄した 後に，洗浄性能を確認する方法の使用例を表 5 に示す。先ず， パーティクルは，もちろん目視では見ることができない小さ なパーティクルであるため, 通常は, レーザ式パーティクル 検査装置と呼ばれる検査機器を使用する。アルゴンなどの レーザをウエハ表面にスキャンして，パーティクルが存在す る場合には，パーティクルサイズに相関した散乱レーザ光量 を検出することによりウエ八表面上のパーティクル位置とサ イズをウエハマップとして表示する(図 4)。現在，市販され ている検査装置として, 検出可能な最も小さなパーティクル サイズは約 $30 \mathrm{~nm}$ 程度と言われている。

次に，金属成分の測定手法について述べる。20 年以上前 時点では，ライフタイム測定方法が主に採用されていたが, この手法は，ライフタイムと金属不純物量を予为測定した データを基準として用いて，ウエハのライフタイムを測定し た値から，金属不純物の付着量を類推する手法である。最近 では，ライフタイム手法に代わって，実際付着している金属 成分量を測定する分析手法を多くの半導体製造会社は採用し ている。つまり, ICP-MS (誘導結合プラズマ質量分析計)や

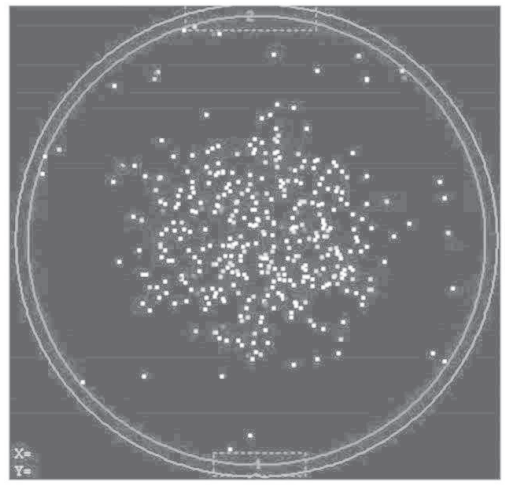

図 4 レーザ式パーティクル測定装置における測定マップ (径 $0.07 \mu \mathrm{m}$ 以上サイズパーティクル検出) 
TXRF（全反射蛍光 X 線反射)である。この手法だと, 検出限 界面では， $1 \mathrm{E} 9 \sim 5 \mathrm{E} 10$ atoms $/ \mathrm{cm}^{2}$ 以下の高感度まで金属成分 の測定が可能である。

最後に有機物測定であるが， GC/MS 手法が一般的に使用さ れている。先端半導体デバイス製造では, クリーンルーム内 に存在する装置, 部材, 薬液などの構成物質からの微量の有 機物ガスが, 製造工程で反応物の形成や異常成長を引き起こ して半導体デバイス歩留まりを低下させていることも判明さ れてきており，各社のノウハウで解決されているようである。

\section{7. その他トピックス}

その他トピックスとして，あまり広く知られていないが， 洗浄・エッチングに扔いて将来にわたり非常に難しい課題に ついて一つ紹介する。図 5, 図 6 に半導体デバイス表面の微 細金属配線が洗浄後に, 金属配線の一部が局所的に消失して しまっている欠陥を示した。図 5 においては，Ruバリア膜 を CMP で除去した後の洗浄後の Cu配線の断面図である。 $\mathrm{Ru}$ バリア膜に接触して成膜されるべき $\mathrm{Cu}$ 膜の一部が局所 的に $\mathrm{Ru}$ 膜との界面に沿って消失しているのがわかる。消失 の原因は, $\mathrm{Ru}$ と $\mathrm{Cu}$ という異種類金属が接触している状態で, $\mathrm{CMP}$ 後洗浄処理中に, 洗浄液 $\sim \mathrm{Ru} \sim \mathrm{Cu} \sim$ 洗浄液の間で電 子の移動が起きてしまい, 結果的に $\mathrm{Cu}$ の一部が洗浄液内へ 溶解してしまったと考えられている。所謂, ガルバニック腐 食と呼ばれている。CMP 後洗浄薬液内の成分として防食剤 を添加することにより $\mathrm{Cu}$ 消失が解決された例である。

また, 図 6 は Al-Si 配線形成のために, ドライエッチング により生成されたデポ生成物を除去するために, 希フッ酸系 薬液を使用して洗浄した例を示した。Al 配線中には $\mathrm{Si}$ ノ ジュール(塊)が局所的に存在するが，Siノジュール周辺部 に沿って，Al消失が発生しているのがわかる。これは，洗 浄液〜 $\mathrm{Al} \sim \mathrm{Si} \sim$ 洗浄液の間で電子の移動が起きてしまい, 結果的に $\mathrm{A} 1$ の一部が洗浄液内一溶解してしまったとためと 考えられる。

以上，2つの例で見られるようなガルバニック腐食の問題 は，配線サイズが微小になるにつれて解決が困難な課題とし て，今後，広く知られるようになると想像できる。多くの種 類の金属を使用して配線を形成していく半導体デバイス製造 に扔いては，ある意味，避けることができない課題と思われ る。今後の, 特に半導体デバイス製造会社と洗浄装置製造会 社の努力に期待したい。

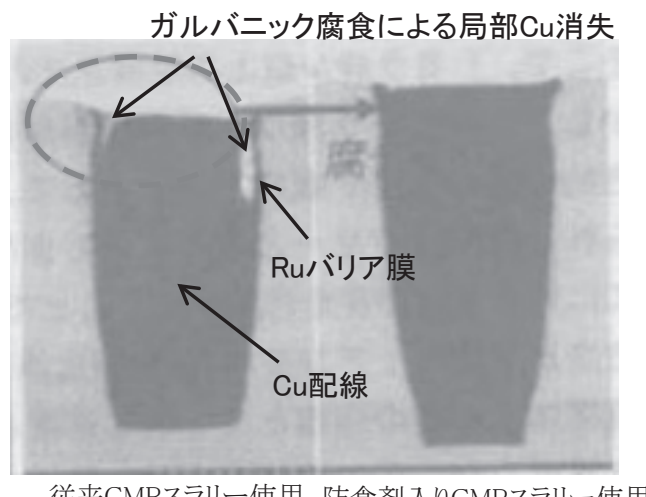

従来CMPスラリー使用 防食剤入りCMPスラリー使用

図 5 ガルバニック腐食と CMP スラリーの防食効果 (出典：2007 年秋季応用物理学会資料 ${ }^{1}$ )

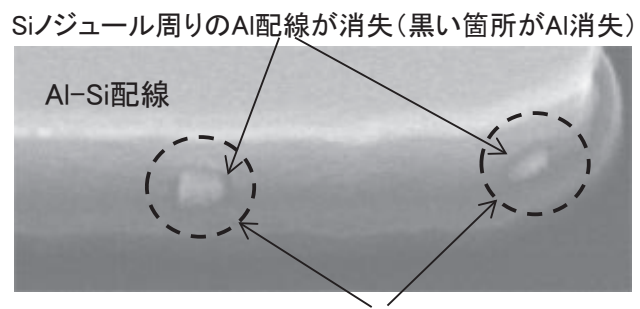

白い箇所がSiノジュール

图 $6 \mathrm{Al}-\mathrm{Si}$ 配線における $\mathrm{Al}$ 局所消失

\section{8.おわりに}

ウエハのウエットエッチング法と洗浄と清浄度について, 簡単に記述してきた。半導体デバイス製造においては, 創成 期から現在に至るまでパーティクルなど不純物との闘いであ ることは将来においても変わらないであろう。そのパーティ クルとの戦いで最も重要な工程は, 洗浄であり, 今後も益々, 重要視されていくと想像している。洗浄技術が日々, 進歩し ていかないと，いずれの日か，半導体デバイスが歩留まり低 下により製造できないという致命的ダメージを受けかねない。 そのような事態にならないように, 関倸者のご活躍に大いに 期待したい。

(Received June 1, 2016)

\section{文献}

1）前田和夫；ビギナーズブックス 17 はじめての半導体プロセス (工業調査会, 2007)

2 ) 丸山浩二, 塩原守雄 ; 2007年秋季応用物理学会, 4p-B-1 (2007). 